\title{
Charakterystyki krainy Sukhāvatī w kontekście przemian buddyjskiej kosmologii i soteriologii. Część pierwsza
}

\author{
Robert SzUKSZTUL
}

\begin{abstract}
Streszczenie
Tekst podejmuje analizę Sukhāvatī - świata („pola buddy”) Amitabhy, określanego również jako Czysta Kraina. Pewne jej cechy - przynajmniej na pozór - odbiegają od standardowych wyobrażeń na temat buddyzmu. Skłaniało to niektórych badaczy do poszukiwań bezpośrednich zapożyczeń z innych religii i kultur, co miało wyjaśnić źródło nazwy, położenie i cechy tej krainy. Charakterystyki te można jednak bardziej przekonująco wyjaśnić, analizując proces ewolucji samego buddyzmu, co stanowi główne zadanie tej pracy.

Tekst podzielony został na dwie części. W części pierwszej przedstawione jest założenie o wewnątrzbuddyjskich źródłach pochodzenia Sukhāvatī wraz z uzasadnieniem tego wyboru. Następnie omówiona zostanie ewolucja buddyjskiej wizji kosmologicznej, która ostatecznie doprowadziła do koncepcji pól buddów, w tym Sukhāvatī. Część druga poświęcona zostanie analizie charakterystyk tej krainy w świetle Krótkiej i Długiej sutry Sukhāvatīvyūha, w kontekście innych tekstów buddyjskich, aby wykazać, że Sukhāvatī skupia w sobie następujące buddyjskie wątki: (a) w warstwie wizualnej przedstawienie raju, (b) w wymiarze niematerialnym aktywność nirwany, (c) w aspekcie ścieżki łatwe praktyki charakteryzujące warunki odrodzenia dla niższych niebios.
\end{abstract}

SŁowA Kluczowe: Sukhāvatī, Czysta Kraina, kosmologia, soteriologia, Amitābha, buddyzm

Robert Szuksztul - filozof i socjolog od wielu lat zajmujący się myślą buddyjską. Zainteresowania badawcze obejmują okres wczesnego buddyzmu - w tym filozofię abhidharmy - oraz tradycję buddyzmu Czystej Krainy.

(iD) https://orcid.org/0000-0002-3733-5184

E-MAIL: robert.szuksztul@uj.edu.pl 


\section{Wykaz skrótów:}

\begin{tabular}{|c|c|}
\hline AKB. & Abhidharmakośabhāṣya \\
\hline AN & Añguttara Nikāya \\
\hline DDB & Digital Dictionary of Buddhism \\
\hline DN & Dīgha Nikāya \\
\hline DSV & Dłuższa Sukhāvatīvyūha sūtra \\
\hline KSV & Krótsza Sukhāvatīvyūha sūtra \\
\hline $\mathbf{M N}$ & Majjhima Nikāya \\
\hline MPPŚ & Mahāprajñāpāramitā śastra/upadeśa \\
\hline $\mathbf{T}$ & $\begin{array}{l}\text { Taishō Shinshū Daizōkyō (大正新脩大藏經) („The SAT Daizōkyō } \\
\text { Text Database” 2018) }\end{array}$ \\
\hline p. & pali \\
\hline SN. & Samyutta Nikāya \\
\hline
\end{tabular}




\section{Wstęp}

Kraina Sukhāvatī - dominium buddy Amitabhy' ${ }^{1}$, jest - w kontekście buddyjskiej kosmologii - oczyszczonym polem buddy. W Azji Wschodniej zaczęto tego rodzaju miejsca określać jako czyste krainy, przy czym w odniesieniu do Sukhāvatī określenie to funkcjonuje de facto jako nazwa własna ${ }^{2}$. Sukhāvatī jest opisywana jako miejsce idealne zarówno w sensie materialnym, jak i niematerialnym - przypominające raj i pozbawione niekorzystnych charakterystyk właściwych zwykłej, ludzkiej egzystencji. W bliskości buddy, przy braku czynników rozpraszających i dzięki wsparciu samej krainy (nawet śpiew ptaków stanowi tam naukę Dharmy) osiągnięcie ostatecznego celu buddyjskiej praktyki jest pewne i szybkie. Osiągnięcie odrodzenia w tej krainie jest $\mathrm{z}$ tego powodu zalecane jako - być może pośrednia - ale optymalna droga do przebudzenia. Zestaw praktyk wymaganych do spełnienia tego celu różni się w zależności od tekstu - w tych najbliżej związanych z kultem Amitabhy jest to (w dodatku do standardowej kultywacji moralności) wizualizacja tego buddy i jego krainy, buddhānusmṛtỉ , czy wzbudzenie mocnego umysłowego postanowienia (sanskr. praṇidhi, p. paṇidhi) i stanu ufności/ zawierzenia (sanskr. śraddhā, p. saddhā; również p. pasanna citta) buddzie. Ostatecznie wątki te zostały skupione w praktyce recytacji imienia tego

1 Prawdopodobnie najbardziej rozpoznawalną dla polskiego czytelnika wersją imienia tego buddy jest (jap.) Amida. W niniejszym tekście przyjęto formę Amitābha, ale należy pamiętać, że w tekstach sanskryckich określany jest on dwoma imionami - Amitābha „Niezmierzone Światło" i Amitāyus „Niezmierzone Życie”. Powstaje pytanie: transkrypcją którego z wymienionych imion jest japoński termin „Amida” (chiń. Āmítuó 阿彌陀); być może żadnego z nich, a jest to po prostu transkrypcja sanskryckiego terminu amita lub amrta? Według Fujity, którego odpowiedź wydaje się najbardziej przekonująca, obie formy: Amitābha i Amitāyus są równie pierwotne, natomiast Amida (chiń. Āmítuó) jest prawidłową transkrypcją ich obu, ponieważ nie odwołuje się do oryginałów sanskryckich, ale do ich zniekształconej formy w prakrycie używanym na terytorium Kuszanów (najprawdopodobniej gandhari), w: Fujita 1996a, 12-13. Innymi słowy, brzmienie obu imion: Amitābha i Amitāyus stało się podobne (albo identyczne) w używanym wówczas w państwie Kuszanów prakrycie, i to tę zniekształconą formę transkrybowano następnie na język chiński.

2 Z tego powodu stosuje się tutaj dwojaki zapis tego określenia: „Czysta Kraina” jako alternatywna nazwa własna Sukhāvatī, albo „czysta kraina” jako termin generyczny na dowolne oczyszczone pole buddy.

${ }^{3}$ O relacji pomiędzy praktyką wizualizacji a wspominaniem buddy (buddhānusmṛti) zob. Harrison (1978). 
buddy. Odrodzenie w Sukhāvatī stało się - co ciekawe - uogólnionym celem praktyki w indyjskiej mahajanie, nawet w tekstach zupełnie niezwiązanych z kultem Amitabhy (Schopen 1977), co pozwala wnosić, że reprezentowany $\mathrm{w}$ niej zestaw charakterystyk konstytuował idealny świat w przekonaniu znacznej części buddystów w Indiach.

Te same jednak charakterystyki prowadziły często do odrzucenia lub marginalizowania tej tradycji lub też dowodzenia jej obcych - niebuddyjskich źródeł. Błoga, praktycznie nieskończona egzystencja w Sukhāvatī wydaje się zaprzeczać prawdzie o bolesności egzystencji i nietrwałości wszelkich zjawisk; wsparcie Amitabhy i samej jego krainy w praktyce buddyjskiej stawia pod znakiem zapytania prawdę o osiąganiu wyzwolenia dzięki własnym i tylko własnym wysiłkom. Mówiąc krótko, buddyzm Czystej Krainy wydaje się zbyt różny od „prawdziwego” buddyzmu, aby zasługiwać na poważne traktowanie. Jest to część szerszego zjawiska, polegającego na przyjęciu przez badaczy założenia o racjonalności, logiczności i naukowości buddyzmu, co prowadzi do pomijania i marginalizowania tych jego aspektów - narracyjnych, metaforycznych, nadnaturalnych czy kosmologicznych - które się w tych założeniach nie mieszczą. Takie podejście skutkuje jednak bardzo jednostronnym i przez to zdeformowanym opisem buddyzmu (Gethin 1997, 184-86), który w większym stopniu ujawnia przedsądy badaczy niż obiektywne cechy buddyzmu.

Prezentowany tutaj tekst opiera się na przeciwnym - całościowym podejściu i podejmuje analizę Sukhāvatī, traktując jej charakterystyki jako kulminację wielowątkowego procesu ewolucji buddyzmu. Wyobrażenie Sukhāvatī stanowi w tej perspektywie soczewkę, poprzez którą możemy dojrzeć gęsty splot idei buddyjskich, ukazać ich połączenia, inspiracje i ewolucję. $\mathrm{Z}$ powodów podanych poniżej proces ten jest traktowany jako czysto buddyjski fenomen, będący skutkiem odpowiedzi na nowe wyzwania związane z redefinicją celu buddyjskiej praktyki, nową wizją kosmologii czy pogłębieniem refleksji dotyczącej natury buddy.

Niniejsza - pierwsza - część tekstu poświęcona jest uzasadnieniu przyjętego założenia o buddyjskich źródłach wyobrażeń o Czystej Krainie, a także przedstawia zarys ewolucji kosmologii buddyjskiej, która doprowadziła do koncepcji oczyszczonych pól buddów, w tym Sukhāvatī.

Część druga podejmuje szczegółową analizę charakterystyk tej krainy, ukazując je w kontekście i jako konsekwencje wcześniejszych idei obecnych w buddyzmie. 


\section{Uzasadnienie założenia o buddyjskich źródłach wyobrażeń o Sukhāvatī}

Na temat pochodzenia Sukhāvatī istnieje wiele teorii. Można je pogrupować w trzy klasy: (1) teorie o genezie pozaindyjskiej, (2) teorie o genezie indyjskiej, lecz niebuddyjskiej, (3) teorie o genezie buddyjskiej.

W koncepcjach pierwszego typu widzę mniej lub bardziej ukryte założenie: wizja Amitabhy - zbawcy istot, władającego „rajem” Sukhāvatī wydaje się zbyt dziwna i oderwana od całokształtu idei i wyobrażeń buddyjskich, aby rozważać jej wewnątrzbuddyjskie pochodzenie. Naturalne wydaje się w takiej sytuacji poszukiwanie podobieństw (terminów, idei, obrazów) w innych kulturach. Zaprezentowanie hipotetycznej ścieżki transmisji obcej idei na grunt buddyjski jest traktowane jako zadowalające rozwiązanie zagadnienia.

Przykładem takiej teorii jest propozycja Iwamoto (1965, 114-119; za: Fujita 1996b, 38; Sadakata i Nakamura 2009, 118-119) wiążąca Sukhāvatī z wizją Edenu i opierająca się na fakcie, że słowo „eden” znaczy po aramejsku „przyjemność”, co natychmiast odnosi do terminu „sukha” (błogość, przyjemność). Co więcej język aramejski, jak i jego alfabet był stosowany w imperium Achemenidów, które graniczyło z Indiami. Z tego alfabetu rozwinęło się w Indiach pismo kharoșthī, a cesarz Aśoka zastosował pismo aramejskie w kilku swoich inskrypcjach. Również wizja Edenu mogła w ten sam sposób dotrzeć do Indii i zostać następnie przekształcona w obraz Sukhāvatī. Iwamoto dopatruje się wielu podobieństw pomiędzy tymi krainami.

Sadakata (2009, 118-119), który przytacza to stanowisko, uważa jednak, że teorii tej nie da się utrzymać. Według niego kierunek zachodni jest niezwykle istotny w sutrach dotyczących Sukhāvatī i trudno wyjaśnić, dlaczego wizja raju na wschodzie zamieniła się w krainę zachodu. Poza tym - twierdzi Sadakata - Sukhāvatī jest krainą, do której udajemy się po śmierci, natomiast Eden nie ma z umieraniem nic wspólnego, będąc miejscem, w którym przed upadkiem mieszkał człowiek i gdzie nie było śmierci. Sam woli wiązać obraz Sukhāvatī z egipskim Amnt i greckim Elizjum, przedstawiając ciekawe rozumowanie, jak egipskie i greckie idee mogły dotrzeć do Indii za pośrednictwem ludów Azji Środkowej, zwłaszcza Kuszanów (Kuṣāna), w których kulturze (na przykład tytulaturze władców) widać istotne wpływy sąsiadów - grecko-rzymskie, irańskie, indyjskie i chińskie (Sadakata i Nakamura 2009, 119-123).

4 Argumentacja ta znajduje się również w polskojęzycznej pozycji Góra Sumeru i kraina Sukhawati. Zarys kosmologii buddyjskiej (Sadakata 2000, 134-40). 
Krótkie podsumowanie krytyczne tego typu teorii można znaleźć u Fujity (doszukiwanie się źródeł kultu Amitabhy i Sukhāvatī na przykład w zoroastryjskim bogu-słońcu, ogrodzie edeńskim czy greckim Elizjum). W odpowiedzi Fujita podkreśla zwyczajny brak dowodów za którąkolwiek z tez, jak również fakt, że w każdym z rzekomych źródeł inspiracji znajdziemy kluczowe niezgodności nazwy lub opisu rajskiej krainy z kluczowymi ideami buddyjskimi:

Żadna jednak z tych teorii nie wytrzymuje naukowej krytyki, ponieważ w każdej z nich albo nazwa, albo też opis Najwyższej Błogości [= Sukhāvatī] jest całkowicie niezgodny z głównym nurtem myśli buddyjskiej. I tak, proponent teorii o ogrodzie edeńskim twierdzi, jak już wcześniej wspomniano, iż termin Sukhāvatī ma źródło w aramejskim słowie Eden, i przyjmuje stanowisko, że zarówno Sukhāvatī, jak i ogród edeński są symbolami reprezentującymi konkretny fenomen pustynnej oazy, z zapałem podkreślając znaczenie tych terminów jako „historycznych obrazów". Sam ów proponent przyznaje jednak, że nie ma na to dowodu. Możemy jedynie ocenić taką teorię jako naciąganą .

Stanowisko to akceptuje Tanaka (1990, 8-9), uwzględnia jednak istotną klaryfikację. Badacz ten uważa, że konkluzje Fujity zostałyby wzmocnione przez lepsze teoretyczne ujęcie procesu oddziaływania jednych kultur na inne. Oddziaływanie to miałoby zachodzić na trzy sposoby: bezpośrednio, eklektycznie lub inspirująco. Biorąc za przykład buddę Amitabhę, przy wpływie bezpośrednim byłby on na przykład Mitrą, którego inkorporowano w całości na grunt buddyjski, nadając inne imię. Wpływ eklektyczny polegałby na przejęciu przez buddyzm pewnych charakterystycznych elementów obcego bóstwa (jak światło) czy obcej tradycji religijnej i włączenie ich we własny system. Oba powyższe mechanizmy zachodzenia wpływów kulturowych łączy to, że mamy tam do czynienia $\mathrm{z}$ bezpośrednim przenoszeniem pewnych idei. Oddziaływanie inspirujące nie zakłada niczego takiego i polega po prostu na odpowiedzi danej tradycji na wyzwanie stawiane przez inną. Buddyzm, konfrontując się z popularnością zbawczych bóstw związanych ze światłem i życiem, obecnych w Indiach Północnych i Azji Środkowej, sięgnąłby tu do własnych zasobów, tworząc postać buddy Amitabhy. Takie właśnie stanowisko prezentuje Tanaka, twierdząc, że jeżeli nawet doszło do transmisji eklektycznej, to w odniesieniu do drugorzędnych cech, najprawdopodobniej

5 Fujita (1996b, 39-40). Tłumaczenie własne. Zob. również Fujita (1970, 17-19; 1996a, 23-24). 
fizycznych charakterystyk Jamy i Waruny. Główną formą oddziaływania obcych tradycji na buddyjskiego Amitabhę byłaby zatem inspiracja do skupienia w jednej postaci oraz amplifikacji cech obecnych w buddyzmie już wcześniej. Oczywiście to samo rozumowanie możemy zastosować do krainy Sukhāvatī.

W niniejszej pracy przyjęte zostało robocze założenie o wewnątrzbuddyjskich źródłach koncepcji Sukhāvatī, a w związku z tym analiza jej charakterystyk będzie prowadzona w wyłącznie buddyjskim kontekście. Powody tego wyboru zostały podane wyżej: nie ma niepodważalnych dowodów na bezpośredni wpływ obcych tradycji na powstanie idei krainy Sukhāvatī, a jednocześnie możemy wskazać na wyraźne cegiełki o buddyjskim rodowodzie, pozwalające zbudować to wyobrażenie. Posługując się rozróżnieniem Tanaki, Elizjum, Amnt czy Eden mogły stanowić inspirację i zarazem wyzwanie dla buddyzmu, w tradycji tej istniały jednak wszystkie potrzebne elementy, aby koncepcja czystych krain w rodzaju Sukhāvatī mogła powstać. Elementy te wydają mi się być mocniejsze i lepiej zintegrowane z całokształtem tradycji buddyjskiej niż cokolwiek, co mogłaby zaproponować jakakolwiek teoria wpływów zewnętrznych. Ten ostatni czynnik (integracja) wydaje mi się najważniejszy i nie dość mocno podkreślany w opracowaniach naukowych. Otóż nawet w przypadku obcych wpływów (inspirujących czy bezpośrednich) na wyobrażenie Sukhāvatī, i tak należy tę koncepcję wyjaśniać w kontekście czysto buddyjskim - z czego wyrasta, co istotnego wnosi do buddyzmu, jakie problemy rozwiązuje itd. Od buddyjskiego kontekstu analizy nie da się uciec, więc lepiej odsunąc niepotwierdzone hipotezy obcych wpływów i zająć się poszukiwaniem źródeł Sukhāvatī w ideach buddyjskich i ich ewolucji. W tym celu warto rozpoczać od zarysowania przemian, jakim ulegała buddyjska kosmologia.

\section{Przemiany buddyjskiej wizji kosmologicznej i ich uwarunkowania}

W buddyzmie można wyróżnić cztery wizje kosmologiczne: (1) kosmologię pojedynczego świata, (2) kosmologię tysięcy, (3) kosmologię niepoliczalności i (4) kosmologie czystych krain, przy czym istnieje istotny związek pomiędzy kosmologią a wizją wyzwolenia (Kloetzli 1983, ix). Każdy z tych schematów wprowadza nowe idee, zachowując jednocześnie bardzo dużo elementów wcześniejszych. 


\subsection{Kosmologia pojedynczego świata}

Najstarsze źródła buddyjskie prezentują pojedynczy system wszechświata (lokadhātu). W obrazie tym, który opisuje również Abhidharmakośabhāṣya (dalej AKB), świat składa się z walca powietrza, na którym opiera się walec wody, na nim zaś walec złota. Na jego obwodzie znajdują się żelazne góry Cakravāla albo Cakravāḍa (p. Cakkavāla), od których system bierze nazwę, utrzymując morze, z którego środka wyłania się góra Sumeru. Ma ona cztery ściany - ze złota, srebra, lapis lazuli i kryształu. Górę otacza siedem uczynionych ze złota koncentrycznych łańcuchów górskich (przedzielonych morzami), o kształcie coraz większych kwadratów. Między najbardziej zewnętrznym z tych łańcuchów a górami Cakravāla rozciąga się wielkie morze - puste, jeśli nie liczyć czterech wielkich wysp-kontynentów, z których południowy - Jambudvīpa (p. Jambudippa) zamieszkujemy my wszyscy. Pozostałe to Uttarakuru na północ od góry Sumeru, Pūrvavideha (p. Pubbavideha) na wschód i Aparagodānīya (p. Aparagoyāna) na zachód.

Cechy wyróżniające kontynent Jambudvīpa to trójkątny kształt, przypominający subkontynent indyjski, z przecinającym go łańcuchem Himalajów. W Himalajach ma rosnąć ogromne drzewo różanej jabłoni, od której kontynent bierze nazwę (Bodhi 2012, 1616). W pobliżu znajduje się jezioro Anavatapta, którego wody cechują się ośmioma pozytywnymi jakościami ${ }^{6}$. Dostać się tam można wyłącznie dzięki niezwykłym mocom (AKB iii 57; Vallée Poussin 1988, II:456).

Wertykalnie świat podzielony jest na sfery lub formy istnienia (31 według źródeł palijskich ${ }^{7}$, będące odpowiednikami i reprezentacjami odpowiednich stanów umysłowych istot. Są one pogrupowane w pewne klasy, które przedstawiam poniżej w porządku malejącej doskonałości, który zgadza się z „geografią” wizji kosmologicznej - sfery znajdujące się wyżej na liście są też wyżej w obrazie kosmologicznym (bardziej szczegółową listę, przedstawioną w postaci zgrabnej tabeli, można znaleźć w Gethin 1997, 194; jeśli chodzi o graficzne podsumowanie na podstawie AKB zob. Kloetzli 1983, 32-39).

6 Woda jest chłodna, czysta, o żywym nurcie, smaczna, świeża, pozbawiona nieprzyjemnych zapachów, łagodna dla gardła i żołądka. Zob. Kloetzli $(1983,25)$. Podobne charakterystyki ma jezioro w Sukhāvatī.

7 Na podstawie źródeł palijskich: Abhidhammatthasanigaha 22-24, Vibhanga 422-426, Visuddhimagga 7:40-44 i 8:29-65, Dīghanikāyațthakathāțīkā 1:217. Za: Gethin (1997, 194). Jak widać, są to późniejsze teksty; w sutrach znajdujemy bardziej wybiórczą prezentację tego materiału, co może być śladem procesu rozbudowywania i porządkowania wizji kosmologicznej. 
- Świat bezforemny (arūpadhātu): 4 niebiosa niepodlegające zniszczeniu:

» Ani postrzeganie, ani niepostrzeganie (nevasañnāāāsaññāyatana)

» Nicość (akiñcaññāyatana)

» Nieskończona świadomość (viññānañuāyatana)

»Nieskończona przestrzeń (ākāsānañcāyatana).

- Świat formy (rūpadhatu): 16 niebios, z których 7 nie podlega zniszczeniu:

- Czwarta jhāna: 7 niebios niepodlegających zniszczeniu

» Czyste wymiary (suddhāvāsa: pięć niebios, gdzie odradzają się niepowracający - akanitțha, sudassin, sudassa, atapa, aviha)

» Nieświadome istoty (asañña satta)

»Wielki owoc/nagroda (vehapphala).

- Trzecia jhāna

» 3 niebiosa niszczone przez kosmiczny kataklizm wiatru (subhakiṇha, appamāṇasubha, parittasubha).

\section{- Druga jhāna}

» 3 niebiosa niszczone przez kataklizm wody lub wiatru (ābhassara, appamānābha, parittābha).

- Pierwsza jhāna

» 3 niebiosa niszczone przez kataklizm ognia, wody lub wiatru (mahābrahmā, brahmapurohita, brahmapārisajja).

- Świat pragnienia (kāmadhātu): 11 wymiarów niszczonych przez kataklizm ognia, wody lub wiatru:

- Wyższe formy odrodzin (sugati): 7 wymiarów

»Sześć światów istot boskich (paranimmitavasavattin, nimmāṇaratin, tusita, yāma, tāvatiṃsa, cātummahārājika)

» Świat istot ludzkich (manussa).

- Niższe formy odrodzin (duggati, apāya): 4 wymiary

»Asurowie (asura)

» Głodne duchy (pettivisaya, petavisaya, petayoni)

»Zwierzęta (tiracchānayoni)

» Istoty cierpiące w piekłach (niraya).

Należy podkreślić, że w tej wizji aspekt kosmologiczny współistnieje z aspektem psychologicznym - żaden nie jest redukowany do drugiego ani postrzegany jako bardziej autentyczny. W zależności od kontekstu rozważania buddyjskie posługują się albo opisem realnych wymiarów, pomiędzy którymi istoty 
transmigrują w wyniku konsekwencji karmicznych, albo psychologicznym opisem cech umysłowych charakterystycznych dla istot przebywających w tych światach (Gethin 1997, 192, 195). Wyjaśnia to opisywaną możliwość odwiedzania umysłem wyższych sfer istnienia przez ludzi, którzy osiągnęli biegłość w kultywacji umysłu. Taką relację przedstawia między innymi DN 11 Kevaddha [Kevatța] sutta (Walshe 1995, 175 nn). Od strony psychologicznej osiągnięcia medytacyjne umożliwiają odczuwanie błogości doświadczanej przez bóstwa ze światów powiązanych z odpowiednim osiągnięciem (na przykład trzecią dhjaną). Zagadnienia systemu cakravāla są oczywiście o wiele bardziej rozbudowane; w kontekście tematu inspiracji dla Sukhāvatī warto zwrócić uwagę na następujące kwestie:

(1) w tej wizji kosmologicznej istnieją sfery - cztery wymiary bezforemne, które nie są w ścisłym sensie miejscem, do którego można trafić. Ich trwanie jest uzależnione i definiowane przez istoty pozostające w odpowiednim pochłonięciu medytacyjnym. Potwierdza to AKB stwierdzeniem „nie ma siedzib ponad Akaniszthą" (Vallée Poussin 1988, II:467). Mówimy zatem o niefizycznym wymiarze kosmosu/egzystencji;

(2) świat podlega periodycznym okresom zniszczenia przez ogień (najczęstszy kataklizm o najmniejszym zasięgu - do sfery pierwszej dhjany włącznie), wodę (rzadszy o zasięgu do drugiej dhjany włącznie) lub powietrze (najrzadszy, sięgający do trzeciej dhjany włącznie). Wynika z tego, że nietrwałość, charakteryzująca sansarę, nie dotyczy pewnej wydzielonej sfery kosmosu (wymiary bezforemne oraz wymiar czwartej dhjany, zawierający między innymi czyste siedziby niepowracających). Mamy zatem tutaj postulat istnienia trwałej strefy kosmosu, która nigdy nie ulegnie zniszczeniu;

(3) Powstaje zagadnienie, co dzieje się z istotami zamieszkującymi rejony niszczone w kataklizmie, na przykład istoty cierpiące w piekłach, których czas jeszcze się nie dopełnił? Pytanie to tradycja buddyjska zadała i udzieliła na nie odpowiedzi. Według Buddhaghosy nie ma istoty w sansarze, która w pewnym momencie nie zasiała nasion karmicznych, umożliwiających odrodzenie w niebie. W czasie kosmicznego kataklizmu karman ten dochodzi do dojrzałości, niejako automatycznie wyciągając istoty w wyższe rejony egzystencji. Nie zgadza się z tym Dhammapāla, który w komentarzu do Buddhaghosy podaje inne rozwiązanie: istoty, które $\mathrm{z}$ różnych powodów nie są $\mathrm{w}$ stanie odrodzić się w wyższych rejonach, odradzają się w tym samym wymiarze (na przykład z piekła do piekła) w innym świecie, który aktualnie nie podlega procesowi zniszczenia. Vasubandhu w AKB podaje obie te możliwości (Gethin 1997, 197-200). Mamy zatem albo założenie o możliwości postępu 
duchowego w wyniku wsparcia czynników zewnętrznych, albo możliwość odrodzenia w innych wszechświatach. Oba wątki zawierają się w wyobrażeniu Sukhāvatī i zostaną wykorzystane w buddyzmie Czystej Krainy;

(4) Czyste wymiary (suddhāvāsa) zawierają ideę osiągnięcia nirwany poprzez odrodzenie w rajskim świecie i ukończenie procesu tam, bez konieczności powracania na ziemię. Jest to bardzo podobne do idei odrodzin w Sukhāvatī;

(5) Powiązanie wymiaru kosmosu ze stanem umysłu można rozszerzyć na zagadnienie sfery odpowiadającej stanowi umysłu buddy. Rozwinięcie koncepcji pola buddy w mahajanie jest logiczną konsekwencją tego powiązania w kosmologii cakravāla;

(6) Bardzo wyraźnie zaznaczony aspekt przestrzenny wertykalny i aspekt czasowy w tej wizji świata (okresy świata, kataklizmy, oczekiwanie na nowego buddę, czas życia w poszczególnych sferach, transmigracja istot poprzez sfery istnienia).

\subsection{Kosmologia tysięcy}

Kosmologia buddyjska dosyć szybko zaczęła się rozbudowywać, za podstawową cegiełkę biorąc opisany wyżej system, zorientowany wokół góry Sumeru. Następnie powielono go w pakiet liczący tysiąc światów i, co typowe dla spekulacji indyjskiej, iterowano następnie tę metodę, tworząc kolejno ideę tysiąca tysiącświatów, a następnie tysiąca jednostek liczących po tysiąc tysiącświatów. Tak powstała idea „trzech tysięcy wielkich tysiącświatów” (sanskr. trisāhasra mahāsāhasra lokadhātu), co oznacza miliard $\left(1000^{3}\right)$ atomowych światów opisanych powyżej. Taki opis zawiera na przykład AN 3.8o, Abhibhū (Bodhi 2012, 313-314) ${ }^{8}$. W sutrze tej Ānanda odnosi się do faktu usłyszanego wcześniej, dotyczącego Abhibhū - ucznia buddy o imieniu Sikhī, który w świecie Brahmy był w stanie wydać z siebie głos, słyszalny w całym tysiącświecie. Anandę interesuje, jaki zasięg głosu miałby sam budda. Śakjamuni odpowiada: „On był uczniem, Anando. Tathagatowie są bez miary” (p. „Sāvako so, ānanda, appameyyā tathāgatā”ti). Ānanda jeszcze dwukrotnie prosi o odpowiedź i ostatecznie Budda zgadza się, prezentując wykład o trzech rodzajach tysiącświatów. Mniejszy tysiącświat (p. sahassi cūlanikā lokadhātu) składa się z tysiąca pojedynczych światów (obejmuje on tysiąc słońc, tysiąc księżyców, tysiąc gór Sumeru itd.). Świat zawierający tysiąc mniejszych tysiącświatów $\left(1000^{2}\right)$ nazywany jest średnim tysiącświatem

8 Sutra ta w edycji Chațtha Sañgāyana ma numer 3.81 i występuje pod tytułem Cụlanikāsuttaṃ. 
do drugiej potęgi (p. dvisahassī majjhimikā lokadhātu), a świat obejmujący tysiąc średnich tysiącświatów $\left(1000^{3}\right)$ określany jest jako wielki tysiącświat do trzeciej potęgi (p. tisahassī mahāsahassī lokadhātu). Budda stwierdza, że głos Tathagaty może przeniknąć cały wielki tysiącświat. Najpierw Tathāgata wypełnia wielki tysiącświat swoim światłem. Kiedy istoty widzą światło, Tathāgata emituje głos i sprawia, że istoty go słyszą. Ananda wyraża zachwyt mocą Buddy, co krytykuje mnich Udāyī. Budda przestrzega przed krytyką Anandy, twierdząc, że gdyby Ananda umarł, nie wykorzeniwszy żądzy, dzięki swojej wierze/ufności w Tathagatę (p. citta pasāda) odrodziłby się siedem razy jako władca bogów i siedem razy jako wielki król na ziemi (mowa o kontynencie Jambudīpa). Budda przewiduje jednak, że Ananda osiągnie nirwanę jeszcze w tym życiu. Zauważmy, że wszystkie te elementy: przepowiednia, wiara/ ufność i jej związek z osiągnięciem dobrego odrodzenia (jako człowiek lub w światach niebiańskich) zostaną przetworzone w tradycji buddyzmu Czystej Krainy i - szerzej - mahajanie. Złożenie w obecności buddy przyrzeczenia osiągnięcia tegoż stanu przez istotę aspirującą do wejścia na ścieżkę bodhisattwy (p. abhinīhārakarana, mūlapanidhāna) jest kluczowym czynnikiem inicjującym ścieżkę, tak jak potwierdzenie (przepowiednia) realizacji tego przyrzeczenia wygłoszone przez buddę.

Warto podkreślić, że zaprezentowany powyżej schemat należy traktować jako wieloświat (system połączonych wszechświatów). Nie ulega wątpliwości, że mimo iż każda cakravāla stanowi w istocie osobny wszechświat, istnieje między nimi kontakt. Z pewnej sutry (AN 10.29, Kosala sutta) wydaje się wynikać, że słońce i księżyc są w stanie oświetlić nie tylko własną ćakrawalę, ale też cały tysiącświat. Według interpretacji przytoczonej wcześniej, istoty mogą w okresie kosmicznego kataklizmu odrodzić się w zupełnie innej ćakrawali. Jak wreszcie widzieliśmy, niektórzy adepci potrafią przeniknąć głosem tysiąc światów; Tathagatowie zaś są zdolni objąć swoim światłem i głosem aż miliard światów. Z tej idei wzięło się utożsamienie pola buddy (sanskr. buddhakșetra), czyli sfery wpływu lub zasięgu jego oddziaływania, z wielkim tysiącświatem.

\subsection{Pole buddy (buddhakșetra)}

Znana w kanonach wczesnego buddyzmu reguła głosi, iż na świecie nie może jednocześnie występować dwóch buddów (MN 115, Bahudhātuka sutta9; DN 19,

9 „ațthānametaṃ anavakāso yaṃ ekissā lokadhātuyā dve arahanto sammāsambuddhā apubbaṃ acarimaṃ uppajjeyyum, netạ̣ thānaṃ vijjatī'ti pajānāti; 'țānañca kho etạ̣ vijjati yạ̣ ekissā lokadhātuyā eko arahạ̣ sammāsambuddho uppajjeyya, țhānametạ̣ vijjatī'ti pajānātì”. 
Mahāgovinda sutta). Wynika to $\mathrm{z}$ tezy, iż Tathāgata nie ma sobie równych $\left(\mathrm{AN}\right.$ 1.174 ${ }^{10}$. Wraz z ewolucją kosmologii regule tej nadano nową interpretację, utożsamiającą „świat” z miliardem atomowych światów cakravāla (wielkim tysiącświatem). Tworzą one „pole buddy” (buddhakșetra) ${ }^{11}$, to jest obszar, na którym działa jeden budda i wiele jego wytworzonych manifestacji. Wytworzeni buddowie (nirmāṇabuddha) są ściśle związani z zadaniem głoszenia Dharmy, będąc głosem buddy w obrębie danego trisāhasra mahāsāhasra lokadhātu ${ }^{12}$. Teorie, że wytworzeni buddowie mogli mówić jedynie wówczas, kiedy mówił budda, konkurowały z innymi twierdzącymi, że mówili oni, tylko gdy rzeczywisty budda milczał; obie teorie zwracały zatem uwagę na ich fantomową egzystencję, uzależnioną od rzeczywistego buddy, którego stanowili przejawy (Kloetzli 1983, 70-71). Można jednak powiedzieć, że jest to pewien nieśmiały krok ku rozwiązaniu kryzysu związanego z odejściem ze świata buddy Śakjamuniego, zwłaszcza że dopuszcza się możliwość działania buddów wytworzonych nawet po parinirwanie (Kloetzli 1983, 67) ${ }^{13}$.

Idea ta zostanie istotnie rozwinięta $\mathrm{w}$ mahajanie, gdzie niepoliczoność pól buddów stanie się centralnym zagadnieniem kosmologii, a możliwość nawiązania kontaktu z aktualnie rezydującymi tam buddami - osią wizji soteriologicznej.

\subsection{Kosmologia niepoliczalności}

Tak zwana kosmologia niepoliczalności, która wiąże się mocno z założeniami mahajany i jednocześnie odpowiada na wynikające $\mathrm{z}$ nich wyzwania ${ }^{14}$, zakłada niepoliczalną ilość światów w 10 kierunkach (regionach). Większość z tych światów tworzy pola buddów. Kosmologia niepoliczalności zachowuje

${ }_{10}$ Zagadnienie to dyskutuje tekst Milindapañha (Pesala 2003, 127).

11 W kosmologii buddyjskiej wyróżnia się pola buddów (1) oczyszczone (viśuddha), (2) nieoczyszczone (aviśuddha), i (3) mieszane (miśraka). Pole czyste jest przyozdobione, nieczyste nieozdobne, a mieszane jest przyozdobione w wybranych miejscach. Inne charakterystyczne cechy czystych pól to brak w nich niebuddystów, niższych sfer odrodzenia czy istot cierpiących. O źródłach i ujęciach tej koncepcji zob. Rowell 1934; 1935; 1937; Williams 2001, 272-276). Bodhisattwowie, przybliżając się do osiągnięcia stanu buddy, oczyszczają przy okazji obszar swojej aktywności. Mahajanistyczne teksty musiały zatem uporać się z problemem ewidentnej nieczystości naszego świata Sahā, obszaru aktywności buddy Śakjamuniego. Streszczenie strategii wyjaśniających ten problem można znaleźć u Williamsa (2001, 273-276).

12 Wydaje się, że ich występowanie ograniczone było zakresem trisāhasra mahāsāhasra lokadhātu, co pozwala traktować obie koncepcje jako ściśle ze sobą powiązane (Kloetzli 1983, 68).

${ }^{13}$ Kloetzli najwyraźniej opiera swoją interpretację na AKB VII 52a (Vallée Poussin 1990, IV:1174).

${ }^{14}$ Co zostanie omówione dalej. 
utożsamienie pola buddy z wielkim tysiącświatem (trisāhasra mahāsāhasra lokadhātu $)^{15}$, numerologia tysięcy światów już tam jednak nie dominuje. To raczej liczba buddów i ich pól, rozsianych w dziesięciu kierunkach, jest istotna i określana jako niepoliczalna - asan்khyeya (także p. asan்khya; asan்kheyya). Kosmologia niepoliczalności, podobnie jak poprzednie, ma przełożenie na tezy dotyczące zakresu oddziaływania buddy, zakresu i granic wszechświata oraz sposobu praktyki. Wizja ta różni się zasadniczo od poprzednich. Rzeczywisty budda z kosmologii asan̉khyeya, zapewniający akces do wszystkich pól równie realnych buddów w dziesięciu regionach, z pewnością nie jest tym samym, co samotny budda (oraz jego manifestacje), którego domeną jest pojedyncze (i jedyne) trisāhasra mahāsāhasra lokadhātu (Kloetzli 1983, 91).

Kosmologia asan̉khyeya zawiera coś więcej niż nowy zestaw liczb. Jej najwyraźniejsza charakterystyka to podkreślenie znaczenia 10 regionów (sanskr. daśadiss) i ich buddów (daśadigbuddha). Kierunki czy regiony (diŝ) są następujące: wschód (pūrvā), południe (dakșināā), zachód (paścimā) i północ (uttarā). Istnieją też cztery pośrednie kierunki (vidiŝ): północny wschód (uttarapūrvā), południowy wschód (pūrvadakșināa), południowy zachód (dakșinapaścimā) i północny zachód (paścimottarā), a także zenit (ūrdhva) i nadir (adhas). Dziesięć kierunków wydaje się przyjmować znaczenie techniczne, w sensie konwencjonalnych granic tak naprawdę nieograniczonego wszechświata. Szczególnie widać to w spekulacjach na temat pól buddów, znajdujących się na granicy światów w tym czy innym kierunku. Na przykład Abhirati leży na wschodniej granicy wszechświatów, a Sukhāvatī na zachodniej. MPPŚ ${ }^{16}$ zapewnia jednak, że nie jest to granica absolutna, a jedynie praktyczna. W Sutrze lotosu znajdujemy wzmiankę o „granicy istniejącego świata" oraz listę szesnastu buddów przebywających w różnych lokalizacjach, jak się można domyślać, na granicy wszechświata (Kloetzli 1983, 99).

Ponieważ nie mamy już do czynienia z pojedynczym polem buddy, sukcesywnie niszczonym i powstającym na nowo (jak w kosmologii tysięcy, związanej z ideą czasu), pojawienie się buddy nie jest już niewyobrażalnie rzadkie; raczej w każdej chwili istnieje niezliczona ilość buddów rezydujących w niezliczonych zakątkach przestrzeni. Za sprawą swojej mocy (głównie iluminacji) pozwalają oni widzieć się i słyszeć różnym zgromadzeniom buddyjskim, co otwiera możliwość bezpośredniego skontaktowania się z rzeczywistym

${ }^{15}$ O pewnych wyjątkach od tej reguły pisze: Kloetzli 1983, 51-52.

${ }^{16}$ Mahāprajñāpāramitā śastra/upadeśa - tekst przypisywany Nagardźunie, będący komentarzem do sutry Pañcaviṃśatisāhasrika prajñāpāramitā. Kloetzli $(1983,8)$ uważa go za główne przedstawienie kosmologii niepoliczalności. 
buddą i wysłuchania jego nauk, a przez to osiągnięcia znaczących postępów na ścieżce. To właśnie stanowi kluczowy zwrot mahajany. Realna obecność buddy jest istotna $\mathrm{z}$ wielu powodów: przyrzeczenie stania się Buddą można złożyć jedynie w obecności buddy. MPPŚ dodaje, że bodhisattwa może uzyskać trzydzieści dwa znaki tylko w obecności buddy. MPPŚ uznaje przy tym argumentację, że wielu buddów nie może przebywać jednocześnie w tym samym czasie i świecie, twierdzi jednak, że należy to ograniczenie rozumieć jako jedno trisāhasra mahāsāhasra lokadhātu. Ponieważ zaś tych jest nieskończona ilość, nie istnieje kalpa pozbawiona obecności buddy. Mnogość realnych buddów dziesięciu regionów z kosmologii niepoliczalności jest silnie przeciwstawiona pojedynczemu buddzie z kosmologii tysięcy, którego jedności nie narusza pojawianie się fantomowych buddów nirmāṇa (Kloetzli 1983, 101-102).

Typowe dla tej nowej kosmologii jest umiejscowienie w jej realiach kosmicznych dramatów pełnych niezwykłości. Można tu wymienić mit o Sukhāvatī, opis wizualizacji buddów i czystej krainy, koncentracje bodhisattwów na dziesiątym bhūmi, opisane w Sūranigamasamādhisūtra, czy opisane w literaturze Pradźniaparamity Wielkie Koncentracje buddy Śakjamuniego w jego kosmicznej formie, umożliwiające dostęp do buddów i ich pól w innych rejonach. Wielkie Koncentracje są fundamentalne dla kosmologii niepoliczalności we wszystkich ich formach, a również są niejako prototypem dla tematu odrodzin w innych światach. $Z$ tego względu warto na nie zwrócić uwagę. Dramat zawarty w literaturze Pradźniaparamity jest obszernie skomentowany w serii 10 aktów, w rozdziałach XIV i XV MPPŚ. W tej opowieści istnieją cztery wyróżnione momenty: (1) wejście Śakjamuniego w stan koncentracji (samādhi), (2) pokaz cudownych mocy - zwłaszcza iluminacji (co natychmiast przywołuje na myśl buddę Amitabhę), (3) uhonorowanie Śakjamuniego przez buddów dziesięciu regionów i buddów dziesięciu regionów przez Śakjamuniego, (4) przekształcenie naszego świata (Sahā) w czystą ziemię $^{17}$. Ujawnienie cudownych mocy jest uzależnione od wejścia buddy w samādhi. Przekształcenie Sahā jest natomiast możliwe po tym, jak przez buddów dziesięciu regionów zostaje Śakjamuniemu ofiarowana pūjā. Jest to jednak możliwe tylko w konsekwencji iluminacji regionów, dokonanej przez Śakjamuniego, co umożliwia zgromadzeniom zobaczenie się i usłyszenie. Stąd opisany dramat może się rozegrać tylko dzięki serii relacji, jakie zachodzą między Śakjamunim a buddami dziesięciu kierunków (Kloetzli 1983, 93-96).

17 A dokładniej „oczyszczone pole buddy”. O relacji między terminami czysta ziemia/kraina a oczyszczone pole buddy zob. część drugą niniejszego tekstu. 
Podsumowując, pomiędzy kosmologią tysięcy a kosmologią niepoliczalności można zarysować następujące różnice:

\begin{tabular}{|l|l|}
\hline Kosmologia sāhasra & Kosmologia asañkhyeya \\
\hline \hline Buddowie wytworzeni (nirmānabuddha) & Realni buddowie 1o regionów \\
\hline Podległość buddów wytworzonych & Równorzędność buddów realnych \\
\hline Procesy soteryczne dzięki działaniu buddy & $\begin{array}{l}\text { Procesy soteryczne dzięki współdziałaniu } \\
\text { wielu buddów }\end{array}$ \\
\hline Moc multiplikacji & Moc iluminacji (światło) \\
\hline Fundamentalna kategoria: czas & Fundamentalna kategoria: przestrzeń \\
\hline Istnieją okresy bez buddy & Zawsze gdzieś istnieje jakiś budda \\
\hline
\end{tabular}

\subsection{Kosmologia czystych krain}

Jak się okaże, wizja Sukhāvatī zaprezentowana w kanonicznych sutrach buddyzmu Czystej Krainy ma bardzo dużo wspólnego z kosmologią niepoliczalności. Jest to zgodne z wnioskami, jakie wysnuł Kloetzli, mówiąc, że kosmologia cakravāla może być rozumiana jako uproszczenie czy skrót kosmologii sāhasra, a kosmologia czystych krain - jako uproszczenie kosmologii asan்khyeya. Należy jednak poczynić tu kilka zastrzeżeń. Po pierwsze, mówiąc o czystych krainach w kontekście generycznym, należy mieć świadomość, że znajdziemy tam wiele elementów kosmologicznych i soteriologicznych, które albo nie odnoszą się do wizji kosmologii asan̉khyeya, albo poza nią wyrastają. Do porównań mamy sutrę Akṣobhyavyūha opisującą działania buddy Akszobhji i jego krainę Abhirati oraz różne wersje sutr Sukhāvatīvyūha. Znajdziemy tam idee i obrazy nawiązujące w niektórych aspektach bardziej wyraźnie do kosmologii pojedynczego świata czy wymiarów niebiańskich. Kosmologia czystych krain, której szczytowym przejawem jest Sukhāvatī, nie jest więc zaledwie jednym z przykładów kosmologii asańkhyeya (chociaż niewątpliwie z niej wyrasta), ale nową wizją. Za sedno tej wizji uważam dwa fakty: (1) ścisłe i intencjonalne połączenie charakterystyk buddy z charakterystykami jego krainy, (2) założenie, że kosmos (Czysta Kraina) nie jest już tylko sceną, na której rozgrywa się wyzwalająca aktywność buddów dziesięciu regionów, lecz raczej aktywnym agensem procesu wyzwolenia i zarazem namacalnym jego przejawem. W kontynuacji tego tekstu zamierzam pokazać, że również 
te nowe idee da się zrozumieć w kontekście idei obecnych we wcześniejszej tradycji buddyjskiej.

\section{Bibliografia}

Bodhi, ed. 2012. The Numerical Discourses of the Buddha: A Translation of the Anguttara Nikāya.

The Teachings of the Buddha. Translated by Bodhi. Boston: Wisdom Publications.

Fujita, Kōtatsu. 1970. Genshi jōdo shisō no kenkyū. Tokyo: Iwanami Shoten.

---. 1996a. Pure Land Buddhism in India. W The Pure Land Tradition: History and De-

velopment, edited by James Foard, Michael Solomon, and Richard K. Payne, 1-42.

Translated by Taitetsu Unno. Berkeley, CA: Berkeley Buddhist Studies Series.

---. 1996b. „The Origin of the Pure Land”. The Eastern Buddhist 29, nr 1: 33-51.

Gethin, Rupert. 1997. „Cosmology and Meditation: From the Aggañña-Sutta to the Mahāyāna”. History of Religions: 183-217.

Harrison, Paul M. 1978. „Buddhânusmṛti in the Pratyutpanna-Buddha-Saṃmukhāvasthita Samādhi-Sūtra”. Journal of Indian Philosophy 6: 35-57.

Iwamoto, Yutaka. 1965. Gokuraku to Jigoku 極楽と地獄 [Sukāvatī and Hell]. Tokyo: San'ichi Shobō.

Kloetzli, Randy. 1983. Buddhist Cosmology: From Single World System to Pure Land: Science and Theology in the Images of Motion and Light. Delhi: Motilal Banarsidass.

La Vallée Poussin, Louis de. 1988. Abhidharmakośabhāṣyam II. Translated by Leo M. Pruden. Berkeley: Asian Humanities Press.

---. 1990. Abhidharmakośabhāṣyam IV. Translated by Leo M. Pruden. Berkeley: Asian Humanities Press.

Pesala. 2003. The Debate of King Milinda: An Abridgement of the Milinda Pañha. [Sydney]: Buddha Dharma Education Association.

Rowell, Teresina. 1934. „The Background and Early Use of the Buddha-Kșetra Concept. Introduction and Chapter One”. The Eastern Buddhist OS06 (3): 199-246.

---. 1935. „The Background and Early Use of the Buddha-Kṣetra Concept. Chapter Two and Three". The Eastern Buddhist OS06 (4): 379-431.

---. 1937. „The Background and Early Use of the Buddha-Kșetra Concept. Chapter Four, with Appendices and Bibliography (Concluded)". The Eastern Buddhist OS07 (2): 132-176.

Sadakata, Akira. 2000. Góra Sumeru i kraina Sukhawati. Zarys kosmologii buddyjskiej. Poznań: Moderski i S-ka.

Sadakata, Akira, Nakamura, Hajime. 2009. Buddhist Cosmology: Philosophy and Origins. Translated by Gaynor Sekimori. Tokyo: Kōsei.

Schopen, Gregory. 1977. „Sukhāvatī as a Generalized Religious Goal in Sanskrit Mahāyāna Sūtra Literature”. Indo-Iranian Journal 19 (3): 177-210.

Tanaka, Kenneth Kenichi. 1990. The Dawn of Chinese Pure Land Buddhist Doctrine: Ching-Ying Hui-Yuan's Commentary on the Visualization Sutra. sanskr. Albany: State University of New York Press (SUNY Series in Buddhist Studies).

The SAT Daizōkyō Text Database. 2018. https://21dzk.l.u-tokyo.ac.jp/SAT2018/master30. php?lang=en.

Walshe, Maurice O’C, ed. 1995. The Long Discourses of the Buddha. Translated by Digha Nikāya. Boston: Wisdom Publications (The Teachings of the Buddha), 1995.

Williams Paul. 2001. Buddyzm Mahajana. Tłum. Henryk Smagacz. Kraków: Wydawnictwo A. 


\title{
Characteristics of The Land of Sukhāvatī in The Context of Changes in Buddhist Cosmology and Soteriology. Part One
}

\begin{abstract}
The text analyses Sukhāvatī - Amitābha's purified buddha field, also known as the Pure Land. The vision of Sukhāvatī became immensely popular in Indian Mahāyāna Buddhism, and in East Asia it started a new Buddhist tradition. Some of its features - at least on the surface - differ from standard ideas about what Buddhism is. The descriptions of the activity of the Buddha Amitābha, who brings salvation to all beings, by enabling them to be reborn and live a blissful and virtually endless existence in his paradise land of Sukhāvatī, where achieving the ultimate goal of Buddhist practice is quick and easy, led to attempts at showing the structural similarities of this tradition with, for example, Christianity. There were also attempts at proving direct borrowings from other religions and cultures, which was supposed to explain the source of the name, location and characteristics of this land. These characteristics, however, can be more convincingly explained by analysing the process of evolution of Buddhism itself, which is the main focus of this work.

Due to its volume, the text is divided in two parts. The first part defends the assumption about the intra-Buddhist origins of Sukhāvatī and the justification for this choice in the context of various other theories about the origin of that land. Then the evolution of the Buddhist cosmological vision that eventually led to the concept of purified buddha fields, including Sukhāvatī, will be discussed. The second part will be devoted to an analysis of the characteristics of this land in the light of the Short and Long Sukhāvatīvyūha sutras, and in the context of other Buddhist texts, to show that Sukhāvatī combines the following Buddhist themes: (a) in the visual layer, the presentation of a paradise, an ideal land that lacks any existential ills, (b) in the non-material aspect, the activity of nirvāna, (c) in the dimension of the Buddhist path, the easy practices that characterise the conditions of rebirth for the lower heavens.
\end{abstract}

KEYWORDs: Sukhāvatī, Pure Land, cosmology, soteriology, Amitābha, Buddhism

RoBert Szuksztul - philosopher and sociologist who has focused on Buddhist thought for many years. Research interests cover the period of early Buddhism, including the philosophy of abhidharma, and the tradition of the Pure Land Buddhism. 